Article

\title{
Chabazite from Campanian Ignimbrite Tuff as a Potential and Sustainable Remediation Agent for the Removal of Emerging Contaminants from Water
}

\author{
Francesco Izzo ${ }^{1}$, Alessio Langella ${ }^{1}$, Bruno de Gennaro ${ }^{2}\left(\mathbb{D}\right.$, Chiara Germinario $^{3, *(\mathbb{D}}$, Celestino Grifa $^{3}$, \\ Concetta Rispoli ${ }^{1}\left[\right.$ and Mariano Mercurio $^{3}$
}

check for updates

Citation: Izzo, F.; Langella, A.; de Gennaro, B.; Germinario, C.; Grifa, C.; Rispoli, C.; Mercurio, M. Chabazite from Campanian Ignimbrite Tuff as a Potential and Sustainable

Remediation Agent for the Removal of Emerging Contaminants from Water. Sustainability 2022, 14, 725. https://doi.org/10.3390/su14020725

Academic Editors: Davide Settembre Blundo, Fernando Enrique García-Muiña, Mauro

Francesco La Russa, Anna

Maria Ferrari and Maria Pia Riccardi

Received: 22 November 2021

Accepted: 6 January 2022

Published: 10 January 2022

Publisher's Note: MDPI stays neutral with regard to jurisdictional claims in published maps and institutional affiliations.

Copyright: (c) 2022 by the authors. Licensee MDPI, Basel, Switzerland. This article is an open access article distributed under the terms and conditions of the Creative Commons Attribution (CC BY) license (https:/ / creativecommons.org/licenses/by/ $4.0 /)$.
1 Department of Earth Sciences, Environment and Resources, Federico II University, Via Cinthia, 80126 Naples, Italy; francesco.izzo4@unina.it (F.I.); alessio.langella@unina.it (A.L.); concetta.rispoli@unina.it (C.R.)

2 Department of Chemical, Materials and Production Engineering, Federico II University, Piazzale V. Tecchio 80, 80125 Naples, Italy; bruno.degennaro@unina.it

3 Department of Sciences and Technology, University of Sannio, Via De Sanctis Snc, 82100 Benevento, Italy; celestino.grifa@unisannio.it (C.G.); mariano.mercurio@unisannio.it (M.M.)

* Correspondence: chiara.germinario@unisannio.it

\begin{abstract}
The technological performance of a chabazite-rich rock belonging to the Campanian Ignimbrite formation, outcropping in the nearby of San Mango sul Calore (southern Italy), has been evaluated for the sorption and release of ibuprofen sodium salt after a surface modification of the starting geomaterial using two different chlorinated surfactants. Equilibrium sorption isotherms and in vitro loading tests demonstrated that the maximum sorption capacities of this geomaterial reach up to 24.5 and $13.5 \mathrm{mg} / \mathrm{g}$, respectively, for zeolite modified with cetylpyridinium and benzalkonium. These results, obtained by non-linear mathematical modeling of the experimental curves, are definitely compatible with the concentrations of the most common non-steroidal anti-inflammatory drugs (such as ibuprofen) in wastewaters, which have been recently considered as contaminants of emerging concern. This investigation also encourages a new possible sustainable exploitation of the lithified yellow facies of Campanian Ignimbrite, although future developments will be focused on using more stable and eco-friendlier two-tailed surfactants.
\end{abstract}

Keywords: minerals; zeolites; chabazite-rich tuff; SMNZ; ibuprofen; NSAIDs; green revolution and ecology transition; water; environment; circular economy

\section{Introduction}

Natural zeolites are highly versatile hydrated tecto-aluminosilicates that constantly give back, since the beginning of their discovery, a high technological added value [1-4]. In a time of deep social and political change, such as the current post-pandemic one, new goals are opening up and are required to be achieved in a short time. On this account, the scientific community is carrying out a huge effort in investigating and promoting new green materials in support of global challenges. Recently, a scientific politically driven debate was also opened in Europe aimed at improving the quality of the climate and the environment (European Green Deal). According to the Italian Recovery and Resilience National Plan [5], the Green Revolution and Ecology Transition should aim at covering some major issues such as: (i) Circular Economy and sustainable agriculture, (ii) renewable energy, (iii) energy efficiency and redevelopment of buildings as well as (iv) protection of land and of water resources [6,7]. Moreover, Murmura et al. [8] highlighted how the industrial sector is affected, in terms of growth, by the driving forces that come from scientific research dealing with technological sustainability. Some high-tech sectors, such as optics and ophthalmic, can represent a valid example of how Industry-4.0-enabling technologies have managed to give useful answers to the market and therefore to the final user, thus matching the right 
balance between research investment and corporate profit. Hence, the call to pay more and more attention to further alternative and sustainable technological proposals also for those sectors unwilling to incorporate this type of change, such as, for example, lithodepuration reclamation processes.

In this frame, natural zeolites could be used, also supported by abundant scientific literature, for the development of composite materials to be used in technologies ready to face the global challenges set out above. In particular, new zeolite-rich nanocomposite materials aimed at applications in the environmental and health sectors are increasingly gaining the scene, thus providing further ideas on the use of these georesources. Actually, natural zeolites properly modified on the surface possess specific properties such as the attitude to adsorb organic molecules and to exchange undesired cations from water.

So far, several attempts have been made to demonstrate the potential and real use of these new zeolite-rich composite materials, as testified by a robust selection of literature [9-12] on several widely occurring natural zeolites, such as clinoptilolite/mordenite, phillipsite and chabazite. In recent years, in addition to the abundant literature on the world's widespread natural clinoptilolite, experiments involving phillipsite, characterized by peculiar chemical and mineralogical features and significant technological potential, are sensibly increasing. By contrast, quite limited information is available on the attitude towards removing emerging contaminants from wastewaters, such as chabazite, another high-performing natural zeolite.

Based on the experience of this research group, this paper aims at highlighting the high-tech features of a natural chabazite zeolite-rich material functionalized with longchain cation surfactants to be potentially used either in the pharmaceutical sector or, more specifically, in the mitigation of the risk of contaminants of emerging concern (i.e., Ibuprofen) in wastewaters. Within this frame, another goal of this study is to suggest a new possible sustainable exploitation of a chabazite-rich geomaterial (Lithified Yellow Tuff) widespread in the Campania region (southern Italy), within the eruptive products attributable to one of the largest eruptions of the last 40,000 years that occurred in the perithyrrenic area: the Campanian Ignimbrite [13].

\section{The Campanian Ignimbrite: Brief Geological, Mineralogical and Exploitation Overview}

The Campanian Ignimbrite (CI) is the most widespread formation of the Phlegraean Fields (Campania region, Italy) and represents the product of the main Quaternary explosive activity in the Mediterranean region, emplacing both pyroclastic fall and flow products [13].

The entire sequence can be divided into different units based on their main lithological features: Plinian Pumice Fall (PPF), Unconsolidated Stratified Ash Flow (USAF), Welded Grey Ignimbrite (WGI), Lithified Yellow Tuff (LYT) and Coarse Pumice Flow (CPF) (Figure 1a).

WGI and LYT have been widely used since historical times and are still used today, mainly as dimension stones in architecture [13].

In the last 20 years, the highly zeolitized LYT has been first deeply investigated and then used for technological applications (e.g., [12] and references therein).

The minerogenetic processes affecting LYT (Figure 1a) start with glass hydrolysis. The glass alteration defines a sodic-potassic environment that allows the crystallization of phillipsite, the predominant zeolite type in the upper part of the facies, and of subordinate chabazite. As the formation of phillipsite proceeds, the system is depleted in $\mathrm{Na}$ with consequent indirect $\mathrm{Ca}$ enrichment, thus defining geochemical conditions more favorable to the crystallization of chabazite.

The easy availability, the low cost and especially the high zeolite content allow this material to also be used for technological applications. Actually, the high cation exchange capacity and adsorption properties, as well as the high selectivity towards several polluting cations and removable water content [14], make these zeolite-rich materials particularly 
suitable in the treatment of urban or industrial wastewater [15], in pharmaceutical applications [16], in agriculture and pedotechnique as soil restoration agents or as slow-release fertilizers, in zootechny and husbandry as binding additives, antiagglomerant agents and food supplements, in the cement technological production as a pozzolanic addition [17] and in thermal energy storage [18]. Moreover, the high feldspar content makes this material exploitable as a substitute for traditional fluxes in ceramic artifacts.

Several Campanian Ignimbrite quarries, most of which are no longer active, are spread throughout the Campania region, but the most exploited areas for production purposes are the Caserta and Nocera-Sarno zones. According to the Regional Plan for Mining Activities in Campania region (Piano Regionale Attività Estrattive, P.R.A.E.) [19], which does not distinguish between WGI and LYT, there are 37 potentially susceptible quarrying areas for Campanian Ignimbrite (Figure 1b,c). Since the last updates related to the regional plan dating 2006, it is possible that some or all the active quarries indicated on the P.R.A.E. (Figure 1c) are no longer active.

Comparing data from the P.R.A.E. and the outcrops of Campanian Ignimbrite reported in [13], the potentially susceptible quarrying areas of LYT are in Sant'Agata dei Goti and Comiziano (Figure 1).
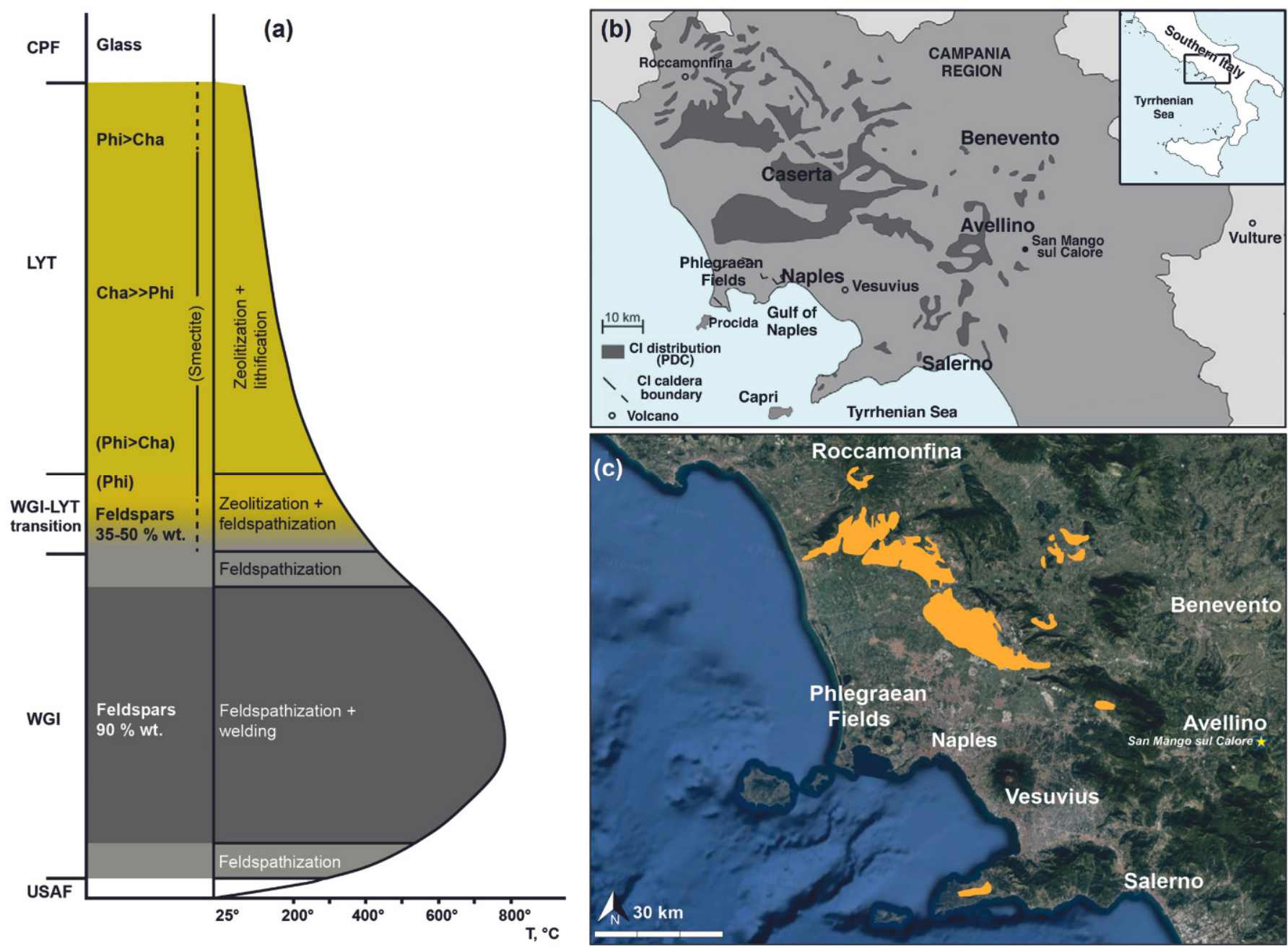

Figure 1. (a) Sketch model of the minerogenetic processes affecting the different units of CI (modified after [13]); (b) Distribution of Campanian Ignimbrite (modified after [20]); (c) Sketch map of potentially susceptible quarrying areas of Campanian Ignimbrite. 


\section{Materials and Methods}

An LYT outcrop located in the municipality of San Mango sul Calore (Avellino) (Figure $1 a, b)$ was the object of this investigation. This is an exceptionally interesting distal outcrop of LYT, especially from a technological point of view due to the high chabazite content.

A recent investigation [21] defined the mineralogical and technological features of this geomaterial, attesting a zeolite content of about $76.4 \mathrm{wt} . \%$, mainly consisting of chabazite $(71.2 \mathrm{wt} . \%)$ and minor phillipsite $(\sim 5.2 \mathrm{wt} . \%)$. K-feldspar ( 16.2 wt.\%), pyroxene $(\sim 3.1 \mathrm{wt} . \%)$, mica $(\sim 1.0 \mathrm{wt.} \%)$ and low-ordered/amorphous phases $(\sim 3.3 \mathrm{wt} . \%)$ also occur. The chemical composition (i.e., $\mathrm{SiO}_{2}, 53.0 \mathrm{wt} . \%$; $\mathrm{Na}_{2} \mathrm{O}+\mathrm{K}_{2} \mathrm{O}, 8.0 \mathrm{wt}$ \%) is typical of the trachytic products of the Phlegraean Fields volcanic district, characterized by a high potassium content $\left(\mathrm{K}_{2} \mathrm{O}, 6.8 \mathrm{wt} . \%\right)$. Chabazite as prevalent phase (empirical formula: $\left[\mathrm{Ca}_{1.17} \mathrm{Na}_{0.18} \mathrm{~K}_{0.80} \mathrm{Mg}_{0.06} \mathrm{Al}_{3.35} \mathrm{Si}_{8.60} \mathrm{O}_{24} \cdot 18.50\left(\mathrm{H}_{2} \mathrm{O}\right)\right]$ [21] is characterized by $\mathrm{Ca}$, $\mathrm{K}$ and Na-dominant extraframework cations (DEC), a medium-low $\mathrm{Si} / \mathrm{Al}$ ratio ( 2.57; $\mathrm{Al}=3.35 \mathrm{apfu})$ and $\mathrm{a} \mathrm{R}=\mathrm{Si} /(\mathrm{Si}+\mathrm{Al})$ of about 0.72 . The theoretical CEC is $3.49 \mathrm{mEq} / \mathrm{g}$, whereas the experimental ECEC average value is $0.229 \mathrm{mEq} / \mathrm{g}$. On the other hand, anion exchange capacity (AEC) is $\sim 0.1 \mathrm{mEq} / \mathrm{g}$ [10].

This chabazite-rich tuff (CHA_SM) was surface modified by the absorption of longchain cation surfactants (cetylpyridinium chloride (CPC) and benzalkonium chloride $(B K C)$ ). The derived SMNZs were tested for loading and release of ibuprofen sodium salt (IBU). Further details about the selected surfactants and drugs are reported in previous papers [12]. As a whole, a suspension containing CHA_SM and each of the selected surfactants (initial concentration of $200 \%$ of the ECEC) was mixed at $8000 \mathrm{rpm}$ at ca. $50{ }^{\circ} \mathrm{C}$ using a high-speed disperser (IKA T25 digital ULTRA TURRAX) for about $70 \mathrm{~min}$ and with a solid-to-liquid (S/L) ratio equal to $1 / 40$, according to the standardized procedures used for the functionalization of other natural geomaterials ([18] and references therein). IBU loading tests were performed on the filtered suspensions, washed and then dried at room temperature.

Equilibrium and kinetics adsorption tests were performed according to the literature [12]. In particular, for the equilibrium adsorption isotherms, SMNZ (100 mg) was treated, under continuous stirring, with $20 \mathrm{~mL}$ of ibuprofen solution (concentrations ranging between 50 and $1000 \mathrm{mg} / \mathrm{L}$ in distilled water), at room temperature after a time sufficient to attain equilibrium (ca. $4 \mathrm{~h}$ ). The supernatant, obtained by separating the liquid from solids through centrifugation, was analyzed by means of an AquaMate UV-VIS spectrophotometer using the adsorption band at $224 \mathrm{~nm}$.

The same quantity of SMNZ was placed, under continuous stirring, in tubes with $20 \mathrm{~mL}$ of IBU solution (concentration $400 \mathrm{mg} / \mathrm{L}$ ) for the kinetic tests. Since the solubility of IBU is $\mathrm{pH}$-dependent [22], for each experiment, the $\mathrm{pH}$ of the solution was adjusted at 7.4 with a sodium tetraborate buffer solution, necessary to keep the IBU molecules in their ionic form. UV-VIS measurements of supernatant permitted to determine non-adsorbed IBU at a scheduled time. All experiments were run in triplicate.

In order to provide a better comparison with the technological performance of previously studied geomaterials [12], in vitro release experiments were carried out using IBU-loaded composites; in particular, for simulating drug release in the intestine, $10 \mathrm{~mL}$ of Simulated Intestinal Fluid (hereafter, SIF) was added to $15 \mathrm{mg}$ of IBU-loaded SMNZ under continuous stirring $(100 \mathrm{rpm})$ in a thermostatic bath $\left(37^{\circ} \mathrm{C}\right)$. At scheduled times, $5 \mathrm{~mL}$ of supernatant, withdrawn by centrifugation and then replaced by the same volume of SIF to ensure sink conditions, was analyzed by spectrophotometric assay. SIF was prepared according to United States Pharmacopoeia $25 \mathrm{Ed}$. and following $\left(68.05 \mathrm{~g} \mathrm{KH}_{2} \mathrm{PO}_{4}, 8.96 \mathrm{~g}\right.$ $\mathrm{NaOH}$, diluted in distilled water to $10 \mathrm{~L}$ ) [10] and references therein.

Experimental data were fitted by non-linear regression, whereas the goodness-of-fit (GOF) of the different mathematical models was evaluated by determination coefficients $\left(\mathrm{R}^{2}\right)$, Bayesian Information Criterion (BIC) and Akaike Information Criterion (AIC). A detailed description of mathematical modeling is reported in previous investigations [12]. 
Starting materials and SMZNs were analyzed with a Bruker Alpha FTIR spectrometer in Attenuated Total Reflectance (ATR) mode (128 scans at a spectral resolution of $4 \mathrm{~cm}^{-1}$ in a spectral range of $400-4000 \mathrm{~cm}^{-1}$ ); the same materials and IBU-loaded SMNZs were also analyzed by Simultaneous Thermal Analyses (thermogravimetry and differential scanning calorimetry, TG/DSC) coupled to Fourier Transform Infrared Spectroscopy for Evolved Gas Analysis (FTIR-EGA). The instrument used is a NETZSCH STA 449 F3 Jupiter, where samples were heated in ultra-pure air $\left(\mathrm{N}_{2} / \mathrm{O}_{2}=80 / 20\right)$ atmosphere (flow $60 \mathrm{~mL} / \mathrm{min}$ ) from room temperature to $1050{ }^{\circ} \mathrm{C}$ (heating rate of $10{ }^{\circ} \mathrm{C} / \mathrm{min}$ ). FTIR-EGA was carried out by means of a BRUKER Tensor 27 instrument, coupled to the STA 449 F3 apparatus by a transfer line heated at a temperature of $200^{\circ} \mathrm{C}$. Data analysis was carried out with Netzsch Proteus 6.1.0 (NETZSCH-Gerätebau $\mathrm{GmbH}$ ) and Opus 7.2 software (Bruker Optics GmbH).

\section{Results and Discussion}

\subsection{Thermal Behavior and Spectral Features}

Thermal behavior, investigated via STA, also responds to the peculiar physicochemical features of zeolitic material and organic compounds (surfactants) that interacted with it. In particular, the starting material shows endothermic peaks at around $168^{\circ} \mathrm{C}$ and $245^{\circ} \mathrm{C}$ (Figure 2) due to the release of zeolitic water from the channels and cages of zeolites [23] (12.6 wt.\%), as confirmed by the detection of water vapor by FTIR-EGA (Figure 2). The definitive structural breakdown occurs at ca. $906{ }^{\circ} \mathrm{C}$, where a broad exothermic peak in the DSC curve appears (Figure 2). The total weight loss slightly increases in both SMNZs, as testified by the occurrence (FTIR-EGA), along with residual zeolitic water, of gaseous compounds related to the thermal decomposition of surfactants (Table 1).

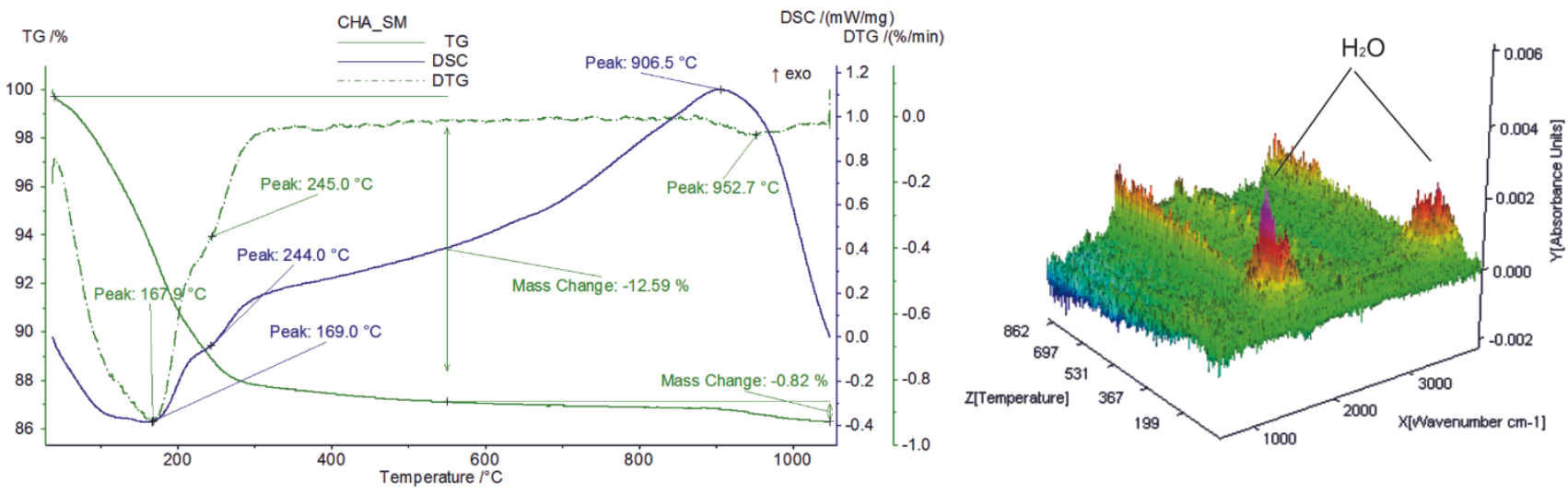

Figure 2. Simultaneous thermal analyses (TG/DSC coupled to FTIR-EGA) of sample CHA_SM (starting geomaterial).

Table 1. Simultaneous Thermal Analyses TG-DSC and FTIR-EGA of the starting geomaterial CHA_SM and SMNZs.

\begin{tabular}{|c|c|c|c|c|c|c|c|}
\hline \multirow{2}{*}{$\begin{array}{l}\text { Starting } \\
\text { Material }\end{array}$} & \multicolumn{3}{|c|}{$\mathrm{T}<550{ }^{\circ} \mathrm{C}$} & \multicolumn{3}{|c|}{$550{ }^{\circ} \mathrm{C}<\mathrm{T}<1050{ }^{\circ} \mathrm{C}$} & \multirow{2}{*}{ L.O.I (\%) } \\
\hline & $\Delta \mathrm{W}(\%)$ & $\operatorname{DSC}^{a}\left({ }^{\circ} \mathrm{C}\right)$ & EGA & $\Delta W(\%)$ & $\operatorname{DSC}^{\mathrm{a}, \mathrm{b}}\left({ }^{\circ} \mathrm{C}\right)$ & EGA & \\
\hline CHA_SM & 12.6 & $169 \div 244$ & $\mathrm{H}_{2} \mathrm{O}$ & 0.8 & $906^{b}$ & - & 13.4 \\
\hline \multirow{2}{*}{ SMNZs } & \multicolumn{3}{|c|}{$\mathrm{T}<200^{\circ} \mathrm{C}$} & \multicolumn{3}{|c|}{$200^{\circ} \mathrm{C}<\mathrm{T}<1050^{\circ} \mathrm{C}$} & \multirow{2}{*}{ L.O.I (\%) } \\
\hline & $\Delta \mathrm{W}(\%)$ & $\operatorname{DSC}^{a}\left({ }^{\circ} \mathrm{C}\right)$ & EGA & $\Delta \mathrm{W}(\%)$ & $\operatorname{DSC}^{\mathrm{a}, \mathrm{b}}\left({ }^{\circ} \mathrm{C}\right)$ & EGA & \\
\hline CHA_CPC & 6.2 & $123 \div 179$ & 13.6 & 7.4 & $\begin{array}{c}251^{\mathrm{b}} \div 332^{\mathrm{b}} \div 497 \\
\mathrm{~b} \div 937^{\mathrm{b}}\end{array}$ & $\begin{array}{c}\mathrm{CO}_{2}+\mathrm{CH}_{3}+\mathrm{CH}_{2}+ \\
\mathrm{H}_{2} \mathrm{O}+\mathrm{CO}^{\operatorname{tr}}\end{array}$ & 13.6 \\
\hline CHA_BKC & 8.3 & 156 & 15.6 & 7.3 & $\begin{array}{c}212^{b} \div 279^{b} \div 382 \\
b \div 506^{b} \div 943^{b}\end{array}$ & $\begin{array}{c}\mathrm{CO}_{2}+\mathrm{CH}_{3}+\mathrm{CH}_{2}+ \\
\mathrm{H}_{2} \mathrm{O}+\mathrm{CO}^{\mathrm{tr}}\end{array}$ & 15.6 \\
\hline
\end{tabular}


FTIR spectroscopy revealed characteristic spectral features for starting material, SMZNs and IBU-loaded SMNZs (Table 2). The starting material showed a very strong band at ca. $999 \mathrm{~cm}^{-1}$ (asymmetric stretching vibrations of T-O bonds) and peaks at ca. 765 and $723 \mathrm{~cm}^{-1}$ (asymmetric and symmetric stretching vibrations in T-O-T bonds, respectively), diagnostic absorption bands associated to internal and external framework vibrations of Primary Building Units (PBUs) and Secondary Building Units (SBUs) of chabazite [24-26]. The other minor bands are generally referred to as the bending vibrations in silicates, whereas the weak bands at ca. $3409 \mathrm{~cm}^{-1}$ and $1637 \mathrm{~cm}^{-1}$ suggest the presence of hygroscopic and zeolitic water (Table 2).

Table 2. FTIR data of starting material (CHA_SM), SMNZs and ibuprofen-loaded composites. CPC, cetylpyridinium chloride; BKC, benzalkonium chloride; IBU, ibuprofen.

\begin{tabular}{|c|c|c|c|c|c|c|}
\hline CHA_SM & CHA_CPC & $\begin{array}{c}\text { CHA_CPC + } \\
\text { IBU }\end{array}$ & CHA_BKC & $\begin{array}{c}\text { CHA_BKC + } \\
\text { IBU }\end{array}$ & $\begin{array}{c}\text { Tentative Vibrational } \\
\text { Assignments }\end{array}$ & $\begin{array}{l}\text { Chemical } \\
\text { Phase }\end{array}$ \\
\hline \multirow[t]{4}{*}{$3409 \mathrm{w}$} & $3406 \mathrm{w}$ & $3428 \mathrm{w}$ & $3388 \mathrm{w}$ & $3415 \mathrm{w}$ & $\mathrm{O}-\mathrm{H}$ stretching & water \\
\hline & $2954 \mathrm{sh}$ & 2953 vw & $2955 \mathrm{sh}$ & 2953 vw & $\mathrm{C}-\mathrm{H}$ stretching & Surfactant/IBU \\
\hline & 2916 w & $2921 \mathrm{w}$ & $2922 \mathrm{vw}$ & $2921 \mathrm{w}$ & $\mathrm{C}-\mathrm{H}$ stretching & Surfactant/IBU \\
\hline & $2850 \mathrm{w}$ & $2851 \mathrm{w}$ & 2852 vw & $2852 w$ & $\mathrm{C}-\mathrm{H}$ stretching & Surfactant/IBU \\
\hline \multirow[t]{5}{*}{$1637 \mathrm{w}$} & $1636 \mathrm{w}$ & $1636 \mathrm{w}$ & $1638 \mathrm{w}$ & $1635 \mathrm{w}$ & $\mathrm{O}-\mathrm{H}$ bending & water \\
\hline & & $1576 \mathrm{vw}$ & & $1574 \mathrm{vw}$ & $\begin{array}{l}\text { Asymmetric stretching } \\
\text { in carboxylate ion }\end{array}$ & IBU \\
\hline & $1489 \mathrm{vw}$ & $1489 \mathrm{vw}$ & $1485 \mathrm{vw}$ & $1489 \mathrm{vw}$ & $\mathrm{C}-\mathrm{H}$ bending & Surfactant/IBU \\
\hline & $1470 \mathrm{vw}$ & $1466 \mathrm{vw}$ & $1470 \mathrm{vw}$ & $1466 \mathrm{vw}$ & $\mathrm{C}-\mathrm{H}$ bending & Surfactant/IBU \\
\hline & & $1381 \mathrm{vw}$ & & $1381 \mathrm{vw}$ & $\begin{array}{l}\text { Symmetric stretching } \\
\text { in carboxylate ion }\end{array}$ & IBU \\
\hline 999 vs & 995 vs & 992 vs & 993 vs & 993 vs & $\begin{array}{l}\mathrm{T}-\mathrm{O} \text { asymmetric } \\
\text { stretching }\end{array}$ & Silicates \\
\hline $765 \mathrm{vw}$ & $777 \mathrm{w}$ & $777 \mathrm{w}$ & $769 w$ & $776 \mathrm{w}$ & $\begin{array}{l}\mathrm{T}-\mathrm{O}-\mathrm{T} \text { asymmetric } \\
\text { stretching }\end{array}$ & Silicates \\
\hline $723 \mathrm{vw}$ & $719 w$ & $721 \mathrm{w}$ & $726 \mathrm{w}$ & $720 w$ & $\begin{array}{l}\mathrm{T}-\mathrm{O}-\mathrm{T} \text { symmetric } \\
\text { stretching }\end{array}$ & Silicates \\
\hline $628 \mathrm{w}$ & $603 \mathrm{w}$ & $599 w$ & $625 \mathrm{w}$ & $599 w$ & $\mathrm{~T}-\mathrm{O}-\mathrm{T}$ bending & Silicates \\
\hline $516 \mathrm{w}$ & $515 \mathrm{vw}$ & $519 \mathrm{vw}$ & $516 \mathrm{w}$ & $517 \mathrm{vw}$ & $\mathrm{T}-\mathrm{O}-\mathrm{T}$ bending & Silicates \\
\hline $461 \mathrm{w}$ & & & $454 \mathrm{w}$ & & $\mathrm{T}-\mathrm{O}-\mathrm{T}$ bending & Silicates \\
\hline $408 w$ & $421 \mathrm{w}$ & $424 \mathrm{w}$ & $408 \mathrm{vw}$ & $422 \mathrm{w}$ & $\mathrm{T}-\mathrm{O}-\mathrm{T}$ bending & Silicates \\
\hline
\end{tabular}

Legend: vw, very weak; w, weak; sh, shoulder; vs, very strong.

CHA_SM composites and ibuprofen-loaded SMNZs are featured by the presence of C-H stretching (3000-2800 $\left.\mathrm{cm}^{-1}\right)$ and C-H bending vibrations (1600-1300 $\mathrm{cm}^{-1}$ ) of surfactants and IBU [27], although IBU-loaded CHA_SM composites show more intense C$\mathrm{H}$ stretching vibration bands [28,29]. On the contrary, IBU-loaded SMNZs are characterized by the presence of bands at ca. $1576 \mathrm{~cm}^{-1}$ and $1380 \mathrm{~cm}^{-1}$ (Table 2) due to the asymmetric and symmetric stretching vibrations of carboxylate ions in the IBU [30].

It is worth noting that the main absorption band at ca. $999 \mathrm{~cm}^{-1}$ seems to be systematically shifted towards lower wavenumbers after the functionalization of the starting material (Table 2), suggesting indirect effects in the internal vibrations of linked tetrahedra.

\subsection{Technological Performance}

According to $\mathrm{R}^{2}$, BIC and AIC values (Table 3), the best-fit of experimental points of equilibrium isotherms was provided by Langmuir [31], Sips [32] and Toth [33] mathematical models (for a detailed description of mathematical modeling refer to specific literature [12]). However, the significant improvement of Goodness-of-fit (GOF) was provided by threeparameters equations (Sips and Toth), as clearly observed in the shape modification of fitting curves (Figure 3).

In particular, best-fit for isotherms was attained implementing Toth equation, which gave a quite perfect asymptotic plateau (Figure 3). GOF confirmed the applicability of this 
model both for CHA_CPC $\left(\mathrm{R}^{2}=0.985 ; \mathrm{AIC}=27.26\right.$; $\left.\mathrm{BIC}=27.10\right)$ and CHA_BKC $\left(\mathrm{R}^{2}=0.998\right.$; $\mathrm{AIC}=6.05 ; \mathrm{BIC}=5.88)($ Table 3$)$.

Table 3. Isotherm parameters of CHA_SM composites.

\begin{tabular}{|c|c|c|c|c|c|c|c|c|}
\hline \multirow[t]{2}{*}{ Sample } & \multirow[t]{2}{*}{ Mathematical Model } & \multicolumn{4}{|c|}{ Parameters } & \multicolumn{3}{|c|}{ Goodness-of-Fit } \\
\hline & & $\mathrm{K}\left(\mathrm{L} \cdot \mathrm{mg}^{-1}\right)$ & $n$ & $\underset{\left(\mathrm{mg} \cdot \mathrm{g}^{-1}\right)}{\mathrm{S}_{\max }}$ & $\underset{\left(\mathrm{mEq} \cdot \mathrm{g}^{-1}\right)}{\mathrm{S}_{\max }}$ & $\mathbf{R}^{2}$ & AIC & BIC \\
\hline \multirow[t]{3}{*}{ CHA_CPC } & Langmuir & 0.01 & & 28.3 & 0.124 & 0.969 & 30.27 & 30.17 \\
\hline & Sips & 0.012 & 1.55 & 25.4 & 0.111 & 0.979 & 29.39 & 29.23 \\
\hline & Toth & 0.006 & 2.95 & 24.4 & 0.107 & 0.985 & 27.26 & 27.1 \\
\hline \multirow[t]{3}{*}{ CHA_BKC } & Langmuir & 0.004 & & 19.8 & 0.087 & 0.969 & 24.07 & 23.96 \\
\hline & Sips & 0.007 & 2.2 & 15.38 & 0.067 & 0.998 & 8.23 & 8.07 \\
\hline & Toth & 0.003 & 5.59 & 14.86 & 0.065 & 0.998 & 6.05 & 5.88 \\
\hline
\end{tabular}

Good results were also obtained for Sips equation $\left(\mathrm{R}^{2}=0.979, \mathrm{AIC}=29.39, \mathrm{BIC}=29.23\right.$ for CHA_CPC; R2 = 0.998, AIC $=8.23, \mathrm{BIC}=8.07$ for CHA_BKC), although the graphic fitting of curves demonstrates that equilibrium conditions are not achieved (Figure 3 ).

By contrast, the shape of curves modeled by the Langmuir equation, one of the most commonly used equations for SMNZs technological performance [4,10,21,34-36] and other geo-materials [31,37-41], shows that the asymptotic plateau both in CHA_CPC $\left(\mathrm{R}^{2}=0.969\right.$ $\mathrm{AIC}=30.27 ; \mathrm{BIC}=30.17)$ and CHA_BKC $\left(\mathrm{R}^{2}=0.969 ; \mathrm{AIC}=24.07 ; \mathrm{BIC}=23.96\right)$ was not reached, although experimental points indicate that equilibrium conditions were achieved (Figure 3; Table 3).
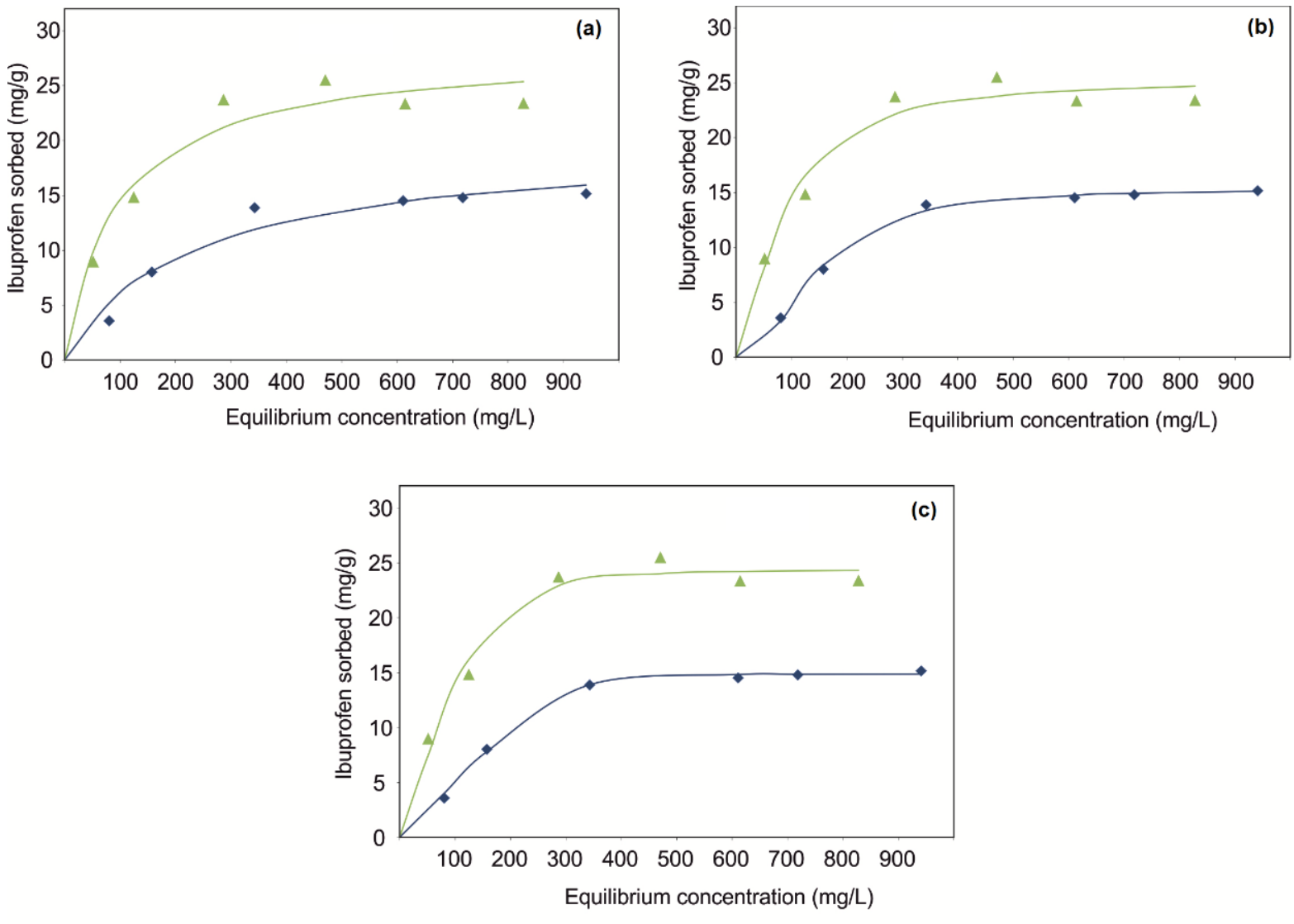

LEGEND: $\rightarrow$ CHA_BKC $\rightarrow$ CHA_CPC

Figure 3. Equilibrium isotherms of CHA_SM composites fitted using Langmuir (a), Sips (b) and Toth (c) mathematical models. 
Therefore, according to Toth equations, maximum sorption capacities $\left(\mathrm{S}_{\max }\right)$ of SMNZs can be estimated ca. $24 \mathrm{mg} / \mathrm{g}$ and $15 \mathrm{mg} / \mathrm{g}$ for CHA_CPC and CHA_BKC, respectively (Table 3). It is worthy that the n parameters (Table 3) are far apart from the unit. Being this parameter indicative of the heterogeneity of the sorption system, sorption mechanisms that characterize the technological performance of CHA_SM composites are very complex and affected by the combination zeolite-surfactant-drug. Therefore, sorption mechanisms should consist in the simultaneous occurrence of anion exchange (predominant) and partitioning in the hydrophobic portion of the micelle.

IBU uptakes onto examined SMNZs were very fast, both using pseudo-first order (PFO) and pseudo-second order (PSO) (Table 4), with almost complete sorption occurring within the first minutes (Figure 4).

Table 4. IBU loading kinetic runs parameters of CHA_SM composites.

\begin{tabular}{|c|c|c|c|c|c|c|c|c|}
\hline \multirow{2}{*}{ Sample } & \multirow[t]{2}{*}{ Mathematical Model } & \multicolumn{4}{|c|}{ Parameters } & \multicolumn{3}{|c|}{ Goodness-of-Fit } \\
\hline & & $K_{1}\left(\min ^{-1}\right)$ & $\underset{\left(\mathrm{g} \cdot \mathrm{mg}^{-1} \cdot \mathrm{min}^{-1}\right)}{\mathrm{K}_{2}}$ & $\begin{array}{c}\mathrm{Q}_{0} \\
\left(\mathrm{mg} \cdot \mathrm{g}^{-1}\right)\end{array}$ & $\underset{\left(\mathrm{mEq} \cdot \mathrm{g}^{-1}\right)}{\mathrm{Q}_{0}}$ & $\mathbf{R}^{2}$ & AIC & BIC \\
\hline \multirow[t]{2}{*}{ CHA_CPC } & Pseudo-first order & 0.244 & & 24.39 & 0.11 & 0.992 & 24.17 & 24.78 \\
\hline & Pseudo-second order & & 0.100 & 24.51 & 0.11 & 0.993 & 23.77 & 24.57 \\
\hline \multirow[t]{2}{*}{ CHA_BKC } & Pseudo-first order & 0.425 & & 13.32 & 0.06 & 0.981 & 21.48 & 22.28 \\
\hline & Pseudo-second order & & 0.107 & 13.46 & 0.06 & 0.981 & 21.38 & 22.18 \\
\hline
\end{tabular}

Comparing the kinetic curves, the maximum amount of loaded IBU reached for CHA_CPC was ca. $24.5 \mathrm{mg} / \mathrm{g}$ (Table 4); a lower amount was instead loaded by CHA_BKC (ca. $13.5 \mathrm{mg} / \mathrm{g}$ ), according to the maximum sorption capacities calculated by equilibrium isotherms using Sips and Toth models. Considering the GOF, a similar trend in the fitting of experimental points can be observed for PFO and PSO equations, although slightly improved in the latter models.
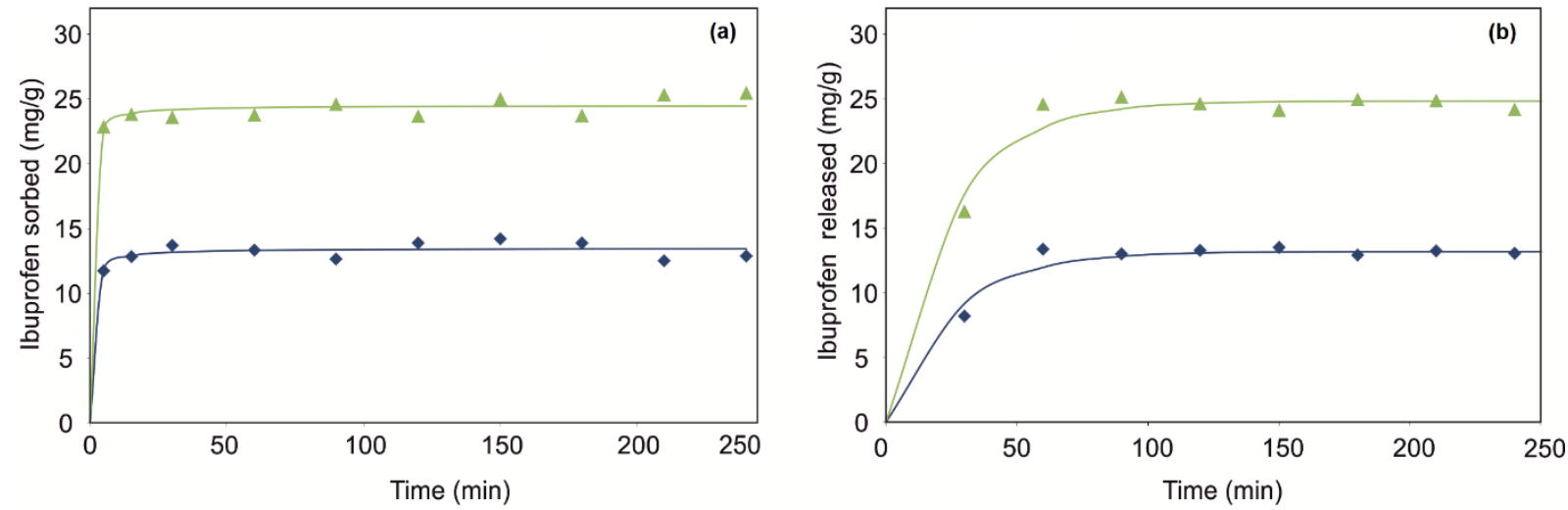

LEGEND: $\rightarrow$ CHA BKC $\_$CHA CPC

Figure 4. Ibuprofen loading (a) and release (b) kinetic runs of CHA_SM composites fitted using pseudo-second-order and pseudo-first-order mathematical models, respectively.

Drug release tests revealed that $50-60 \%$ of IBU was fast released by both CHA_CPC and CHA_BKC samples; most of the drug is released in the first $30 \mathrm{~min}$ and completed within the first hour (Figure 4). Non-linear regression suggested that the best-fit was obtained by the first-order mathematical model for both CHA_CPC $\left(\mathrm{R}^{2}=0.987\right.$, AIC $=30.72$, $\mathrm{BIC}=31.52)$ and CHA_BKC $\left(\mathrm{R}^{2}=0.978, \mathrm{AIC}=23.13, \mathrm{BIC}=23.92\right)$. 


\section{Conclusions}

As a matter of fact, global industrial and technological development defines a great impact on the quality of environmental matrices such as air, soils, subsoil and water systems. It is clearly demonstrated by the high level of xenobiotic compounds daily released in water bodies, often responsible for negative effects on living beings in terms of toxicity and persistence. Among them, particular attention is recently paid to the socalled emerging contaminants [42-46] consisting of several groups of chemicals, such as, for example, pesticides, personal care products, steroid hormones and pharmaceuticals. The latter represents one of the most common groups of emerging contaminants. In fact, the massive consumption of "over-the-counter" drugs, such as NSAIDs (e.g., ibuprofen, ketoprofen, diclofenac, naproxen, etc.), led to an increase in the level of these emerging contaminants also in the municipal waters and consequently in the wastewater treatment plants (WWPTs) $[47,48]$. Nevertheless, NSAIDs are not completely removed from WWPTs and, in spite of the promising results, there are some negative aspects with conventional tertiary treatments (e.g., advanced oxidation processes, adsorption on activated carbon, etc.) in terms of costs and possible harmful by-products $[49,50]$. For these reasons, a chabaziterich tuff functionalized using two chlorinated surfactants has been here examined for the sorption of the NSAID ibuprofen sodium salt in order to promote an alternative and low-cost adsorption system that also provides a new possible sustainable exploitation of the lithified yellow facies of Campanian Ignimbrite. Generally, in terms of advantages and benefits, natural zeolites should be preferred to synthetic ones since the latter, although showing a good technological performance in IBU sorption [51], is normally produced in more expensive and energy-intensive industrial processes.

As a whole, the preliminary results of this research demonstrate that maximum sorption capacities of SMNZs prepared with functionalized chabazite-rich tuff outcropping in the near San Mango sul Calore (southern Italy) are definitely full compatible with the concentrations of emerging contaminants reported in the literature for water bodies. In particular, maximum sorption capacities of these composites reach up to 24.5 and 13.5 $\mathrm{mg} / \mathrm{g}$, respectively, for chabazite modified with CPC and BKC, which is quite consistent with the performances of other organomineral composites reported in the literature, as summarized in Table 5. Taking into consideration also the parameters of in vitro release tests, lithified yellow facies of Campanian Ignimbrite also displays a promising performance in the drug delivery applications [10-12], although future investigations are required and will address the use of more stable and eco-friendlier two-tailed surfactants. Moreover, additional experiments aiming to evaluate the interference effects with inorganic anions usually contained in real aqueous systems are strictly required ([52] and references therein).

Table 5. Drug sorption capacities of surfactant-modified CHA_SM (present study) compared with those of other organomineral composites from literature (main mineral abbreviations form [53]). Legend: Cbz, chabazite; Php, phillipsite; Sme, smectite; Cpt, clinoptilolite; Mnt, montomorillonite; Kln, kaolinite; IBU, ibuprofen; DCF, diclofenac; KET, ketoprofen; NAP, naproxen; SA, salicylic acid; DDEA, diclofenac diethylamine; $\mathrm{CPC}$, cetylpyridinium chloride; $\mathrm{BKC}$, Benzalkonium chloride; HDTMA-Cl, hexadecyltrimethylammonium chloride; HDTMA-Br, hexadecyltrimethylammonium bromide; ARQ, Arquad; ODMBA, octadecyldimethylbenzylammonium chloride; n.a., not available; *, included references therein.

\begin{tabular}{|c|c|c|c|c|c|c|}
\hline ID Sample & Description & $\begin{array}{l}\text { Adsorbent } \\
\text { Minerals }\end{array}$ & Drug & Surfactant & $\mathrm{S}_{\max }$ & Reference \\
\hline \multirow{2}{*}{ CHA_SM } & \multirow{2}{*}{$\begin{array}{c}\text { Campanian Ignimbrite } \\
\text { (Lithified Yellow Tuff) from } \\
\text { San Mango sul Calore } \\
\text { (southern Italy) }\end{array}$} & \multirow{2}{*}{$\begin{array}{l}\mathrm{Cbz}(71.2 \text { wt.\%), } \\
\text { Php (5.2 wt.\%) }\end{array}$} & $\begin{array}{l}\text { IBU } \\
\text { IBU }\end{array}$ & $\begin{array}{l}\mathrm{CPC} \\
\mathrm{BKC}\end{array}$ & $\begin{array}{l}24.5 \mathrm{mg} / \mathrm{g} \\
13.5 \mathrm{mg} / \mathrm{g}\end{array}$ & $\begin{array}{l}\text { Present study } \\
\text { Present study }\end{array}$ \\
\hline & & & DCF & $\mathrm{CPC}$ & $21.3 \mathrm{mg} / \mathrm{g}$ & [10] \\
\hline
\end{tabular}


Table 5. Cont.

\begin{tabular}{|c|c|c|c|c|c|c|}
\hline ID Sample & Description & $\begin{array}{l}\text { Adsorbent } \\
\text { Minerals }\end{array}$ & Drug & Surfactant & $S_{\max }$ & Reference \\
\hline \multirow{7}{*}{ PHI_SAV } & \multirow{7}{*}{$\begin{array}{c}\text { Neapolitan Yellow Tuff from } \\
\text { Savanelli quarry (southern } \\
\text { Italy) }\end{array}$} & \multirow{7}{*}{$\begin{array}{l}\text { Cbz ( } 4.5 \text { wt. } \%) \\
\text { Php (69.6 wt. } \%)\end{array}$} & IBU & CPC & $19.3 \mathrm{mg} / \mathrm{g}$ & [12] \\
\hline & & & IBU & CPC & $22 \mathrm{mg} / \mathrm{g}$ & [54] \\
\hline & & & IBU & $\mathrm{BKC}$ & $20.9 \mathrm{mg} / \mathrm{g}$ & [12] \\
\hline & & & IBU & HDTMA-Cl & $26.4 \mathrm{mg} / \mathrm{g}$ & [12] \\
\hline & & & IBU & HDTMA-Br & $27.9 \mathrm{mg} / \mathrm{g}$ & [12] \\
\hline & & & DCF & $\mathrm{CPC}$ & $65 \mathrm{mg} / \mathrm{g}$ & [54] \\
\hline & & & DCF & $\mathrm{CPC}$ & $45.1 \mathrm{mg} / \mathrm{g}$ & [10] \\
\hline \multirow{10}{*}{ PHIL75 } & \multirow{10}{*}{$\begin{array}{l}\text { Phillipsite-rich rock from } \\
\text { Campania Region } \\
\text { (commercialized by Italiana } \\
\text { Zeoliti-CBKC Group) }\end{array}$} & \multirow{10}{*}{$\begin{array}{l}\text { Cbz (4.0 wt. } \%) \\
\text { Php (44.0 wt. } \%) \\
\text { Sme (11 wt. } \%)\end{array}$} & IBU & CPC & $17.9 \mathrm{mg} / \mathrm{g}$ & {$[52] *$} \\
\hline & & & IBU & ARQ & $4.8 \mathrm{mg} / \mathrm{g}$ & {$[52] *$} \\
\hline & & & DCF & $\mathrm{CPC}$ & $30 \mathrm{mg} / \mathrm{g}$ & {$[52]^{*}$} \\
\hline & & & DCF & ARQ & $19.9 \mathrm{mg} / \mathrm{g}$ & {$[52] *$} \\
\hline & & & KET & $\mathrm{CPC}$ & $12.5 \mathrm{mg} / \mathrm{g}$ & {$[52] *$} \\
\hline & & & KET & ARQ & $10.9 \mathrm{mg} / \mathrm{g}$ & {$[52] *$} \\
\hline & & & NAP & $\mathrm{CPC}$ & $17.9 \mathrm{mg} / \mathrm{g}$ & [52] * \\
\hline & & & NAP & ARQ & $4.8 \mathrm{mg} / \mathrm{g}$ & [52] * \\
\hline & & & SA & $\mathrm{CPC}$ & $10.0 \mathrm{mg} / \mathrm{g}$ & {$[52] *$} \\
\hline & & & SA & ARQ & $4.4 \mathrm{mg} / \mathrm{g}$ & {$[52]^{*}$} \\
\hline \multirow{5}{*}{ CLI_SK } & \multirow{5}{*}{$\begin{array}{l}\text { Clinoptilolite-rich rock from } \\
\text { Nižný Hrabovec deposit } \\
\text { (East-Slovakia basin) }\end{array}$} & \multirow{5}{*}{ Cpt (55.7 wt.\%) } & IBU & $\mathrm{CPC}$ & $16.9 \mathrm{mg} / \mathrm{g}$ & [12] \\
\hline & & & IBU & $\mathrm{BKC}$ & $15.0 \mathrm{mg} / \mathrm{g}$ & [12] \\
\hline & & & IBU & HDTMA-Cl & $22.5 \mathrm{mg} / \mathrm{g}$ & [12] \\
\hline & & & IBU & HDTMA-Br & $25.9 \mathrm{mg} / \mathrm{g}$ & [12] \\
\hline & & & $\mathrm{DCF}$ & $\mathrm{CPC}$ & $49.0 \mathrm{mg} / \mathrm{g}$ & [10] \\
\hline CLI_CA & $\begin{array}{c}\text { Clinoptilolite-rich rock from } \\
\text { California, USA } \\
\text { (commercialized by St. Cloud } \\
\text { Mining Company) }\end{array}$ & Cpt (80.0 wt.\%) & DCF & $\mathrm{CPC}$ & $40.3 \mathrm{mg} / \mathrm{g}$ & [11] \\
\hline \multirow{4}{*}{ ZVB } & \multirow{4}{*}{$\begin{array}{l}\text { Clinoptilolite-rich tuff from } \\
\text { the Zlatokop mine (Vranjska } \\
\text { Banja, Serbia) }\end{array}$} & \multirow{4}{*}{ Cpt (80 wt.\%) } & IBU & $\mathrm{BKC}$ & $13.1 \mathrm{mg} / \mathrm{g}$ & [29] \\
\hline & & & DCF & CPC & $42.9 \mathrm{mg} / \mathrm{g}$ & [55] \\
\hline & & & DCF & HDTMA-Br & $54.1 \mathrm{mg} / \mathrm{g}$ & [56] \\
\hline & & & DDEA & $\mathrm{BKC}$ & $37.3 \mathrm{mg} / \mathrm{g}$ & [29] \\
\hline NZ-BKC & $\begin{array}{l}\text { Clinoptilolite-rich tuff from } \\
\text { the Zlatokop mine (Vranjska } \\
\text { Banja, Serbia) }\end{array}$ & Cpt (73 wt.\%) & SA & $\mathrm{BKC}$ & $19.0 \mathrm{mg} / \mathrm{g}$ & [57] \\
\hline \multirow{10}{*}{ IZ_CLI } & \multirow{10}{*}{$\begin{array}{l}\text { Clinoptilolite-rich tuff from } \\
\text { Eskişehir (Turkey) }\end{array}$} & \multirow{10}{*}{ Cpt (79.0 wt.\%) } & IBU & $\mathrm{CPC}$ & $19.7 \mathrm{mg} / \mathrm{g}$ & {$[52] *$} \\
\hline & & & IBU & ARQ & $12.5 \mathrm{mg} / \mathrm{g}$ & {$[52] *$} \\
\hline & & & DCF & $\mathrm{CPC}$ & $35 \mathrm{mg} / \mathrm{g}$ & [52] * \\
\hline & & & DCF & ARQ & $23.3 \mathrm{mg} / \mathrm{g}$ & {$[52] *$} \\
\hline & & & KET & СРC & $13.6 \mathrm{mg} / \mathrm{g}$ & {$[52]^{*}$} \\
\hline & & & KET & ARQ & $9.3 \mathrm{mg} / \mathrm{g}$ & [52] * \\
\hline & & & NAP & $\mathrm{CPC}$ & $16.1 \mathrm{mg} / \mathrm{g}$ & {$[52] *$} \\
\hline & & & NAP & ARQ & $7.7 \mathrm{mg} / \mathrm{g}$ & {$[52] *$} \\
\hline & & & SA & $\mathrm{CPC}$ & $11.0 \mathrm{mg} / \mathrm{g}$ & {$[52] *$} \\
\hline & & & SA & ARQ & $8.5 \mathrm{mg} / \mathrm{g}$ & {$[52]^{*}$} \\
\hline \multirow[b]{2}{*}{$\mathrm{HZ}$} & \multirow{2}{*}{$\begin{array}{l}\text { Commercial zeolite (Wangpyo } \\
\text { Chemical Co., Pohang, Korea) }\end{array}$} & \multirow[b]{2}{*}{ n.a. } & IBU & HDTMA-Cl & $13.6 \mathrm{mg} / \mathrm{g}$ & [58] \\
\hline & & & SA & HDTMA-Cl & $3.3 \mathrm{mg} / \mathrm{g}$ & [58] \\
\hline \multirow[b]{2}{*}{$\mathrm{HM}$} & \multirow{2}{*}{$\begin{array}{l}\text { Montomorillonite-KSF } \\
\text { (Aldrich Chemical Co., } \\
\text { Munich, Germany) }\end{array}$} & \multirow[b]{2}{*}{ Mnt } & IBU & HDTMA-Cl & $13.5 \mathrm{mg} / \mathrm{g}$ & [58] \\
\hline & & & SA & HDTMA-Cl & $5.9 \mathrm{mg} / \mathrm{g}$ & [58] \\
\hline $\mathrm{OM}$ & $\begin{array}{l}\text { Bentonite obtained from } \\
\text { Šipovo deposit (Bosnia) }\end{array}$ & Mnt (90 wt.\%) & SA & ODMBA & $3.2 \mathrm{mg} / \mathrm{g}$ & [59] \\
\hline OK & $\begin{array}{l}\text { Kaolin from a plant for } \\
\text { production of quartz sand in } \\
\text { Rgotina (Serbia) }\end{array}$ & Kln & SA & ODMBA & $4.8 \mathrm{mg} / \mathrm{g}$ & [59] \\
\hline
\end{tabular}


Nevertheless, the results of this research promote a more efficient water purification process that fits the aims of the European Green Deal mission, mainly consisting of the improvement of the quality of inland and marine water systems, as well as their resilience. It should be added that the functionalized zeolites, regardless of the emerging contaminant to be removed, can also be recycled in other uses such as those involving high-temperature treatments, as those required, for example, in the production of lightweight aggregates in the industrial building sector.

Author Contributions: Conceptualization, F.I., A.L. and M.M.; methodology, F.I., A.L., B.d.G. and M.M.; investigation, F.I., B.d.G. and C.G. (Chiara Germinario); resources, A.L. and M.M; data curation, C.G. (Celestino Grifa); writing-original draft preparation, F.I., A.L. and M.M.; writing-review and editing, F.I., A.L., B.d.G., C.G. (Chiara Germinario), C.G. (Celestino Grifa), C.R. and M.M.; visualization, F.I., C.G. (Chiara Germinario) and C.R.; supervision, A.L. and M.M.; project administration, A.L. and M.M.; funding acquisition, A.L. and M.M. All authors have read and agreed to the published version of the manuscript.

Funding: This research was funded by FRA 2019-2020 to Mariano Mercurio and Alessio Langella. Chiara Germinario was supported by a research grant on the project PON AIM1845378-1; CUP: F84I19000040001 within further investigations have been performed. Francesco Izzo was supported by a research grant on the project PON "Ricerca e Innovazione" 2014-2020 (PON R\&I) —Azione IV.6-“Contratti di ricerca su tematiche Green"; CUP: E65F21003260003.

Institutional Review Board Statement: Not applicable.

Informed Consent Statement: Not applicable.

Data Availability Statement: The data presented in this study are available on the request from the corresponding author.

Acknowledgments: The authors thank Piergiulio Cappelletti for his support in the acquisition of the preliminary mineralogical data.

Conflicts of Interest: The authors declare no conflict of interest.

\section{References}

1. Misaelides, P. Application of natural zeolites in environmental remediation: A short review. Microporous Mesoporous Mater. 2011, 144, 15-18. [CrossRef]

2. Bowman, R.S. Applications of surfactant-modified zeolites to environmental remediation. Microporous Mesoporous Mater. 2003, 61, 43-56. [CrossRef]

3. Reeve, P.J.; Fallowfield, H.J. Natural and surfactant modified zeolites: A review of their applications for water remediation with a focus on surfactant desorption and toxicity towards microorganisms. J. Environ. Manage. 2018, 205, 253-261. [CrossRef] [PubMed]

4. Wang, S.; Peng, Y. Natural zeolites as effective adsorbents in water and wastewater treatment. Chem. Eng. J. 2010, 156, 11-24. [CrossRef]

5. Italian Council of Ministers. Recovery and Resilience Plan; European Parliamentary Research Service(EPRS): Brussels, Belgium, 2021.

6. Vacchi, M.; Siligardi, C.; Demaria, F.; González-Sánchez, R.; Settembre-Blundo, D. Technological Sustainability or Sustainable Technology? A Multidimensional Vision of Sustainability in Manufacturing. Sustainability 2021, 13, 9942. [CrossRef]

7. Cavalieri, A.; Reis, J.; Amorim, M. Circular economy and internet of things: Mapping science of case studies in manufacturing industry. Sustainability 2021, 13, 3299. [CrossRef]

8. Murmura, F.; Bravi, L.; Santos, G. Sustainable process and product innovation in the eyewear sector: The role of industry 4.0 enabling technologies. Sustainability 2021, 13, 365. [CrossRef]

9. Suazo-Hernández, J.; Sepúlveda, P.; Manquián-Cerda, K.; Ramírez-Tagle, R.; Rubio, M.A.; Bolan, N.; Sarkar, B.; Arancibia-Miranda, N. Synthesis and characterization of zeolite-based composites functionalized with nanoscale zero-valent iron for removing arsenic in the presence of selenium from water. J. Hazard. Mater. 2019, 373, 810-819. [CrossRef]

10. Serri, C.; de Gennaro, B.; Catalanotti, L.; Cappelletti, P.; Langella, A.; Mercurio, M.; Mayol, L.; Biondi, M. Surfactant-modified phillipsite and chabazite as novel excipients for pharmaceutical applications? Microporous Mesoporous Mater. 2016, 224, 143-148. [CrossRef]

11. de Gennaro, B.; Catalanotti, L.; Cappelletti, P.; Langella, A.; Mercurio, M.; Serri, C.; Biondi, M.; Mayol, L. Surface modified natural zeolite as a carrier for sustained diclofenac release: A preliminary feasibility study. Colloids Surfaces B Biointerfaces 2015, 130, 101-109. [CrossRef] [PubMed] 
12. Izzo, F.; Mercurio, M.; de Gennaro, B.; Aprea, P.; Cappelletti, P.; Daković, A.; Germinario, C.; Grifa, C.; Smiljanic, D.; Langella, A. Surface modified natural zeolites (SMNZs) as nanocomposite versatile materials for health and environment. Colloids Surfaces $B$ Biointerfaces 2019, 182, 110380. [CrossRef] [PubMed]

13. Langella, A.; Bish, D.L.; Cappelletti, P.; Cerri, G.; Colella, A.; de Gennaro, R.; Graziano, S.F.; Perrotta, A.; Scarpati, C.; de Gennaro, M. New insights into the mineralogical facies distribution of Campanian Ignimbrite, a relevant Italian industrial material. Appl. Clay Sci. 2013, 72, 55-73. [CrossRef]

14. Esposito, S.; Marocco, A.; Dell'Agli, G.; De Gennaro, B.; Pansini, M. Relationships between the water content of zeolites and their cation population. Microporous Mesoporous Mater. 2015, 202, 36-43. [CrossRef]

15. Colella, C.; Pansini, M. Lead removal from wastewaters using chabazite tuff. ACS Symp. Ser. 1988, 368, 500-510.

16. Cerri, G.; Farina, M.; Brundu, A.; Daković, A.; Giunchedi, P.; Gavini, E.; Rassu, G. Natural zeolites for pharmaceutical formulations: Preparation and evaluation of a clinoptilolite-based material. Microporous Mesoporous Mater. 2016, 223, 58-67. [CrossRef]

17. Özen Karsli, S.; Göncüoğlu, M.; Liguori, B.; de Gennaro, B.; Cappelletti, P.; Gatta, G.; Iucolano, F.; Colella, C. A comprehensive evaluation of sedimentary zeolites from Turkey as pozzolanic addition of cement-and lime-based binders. Constr. Build. Mater. 2016, 105, 46-61. [CrossRef]

18. Basile, A.; Cacciola, G.; Colella, C.; Mercadante, L.; Pansini, M. Thermal conductivity of natural zeolite-PTFE composites. Heat Recover. Syst. CHP 1992, 12, 497-503. [CrossRef]

19. Campania Region. PRAE (Regional Plan of the Exploiting Activities in Campania Region); Campania Region: Campania, Italy, 2006.

20. Scarpati, C.; Sparice, D.; Perrotta, A. A crystal concentration method for calculating ignimbrite volume from distal ash-fall deposits and a reappraisal of the magnitude of the Campanian Ignimbrite. J. Volcanol. Geotherm. Res. 2014, 280, 67-75. [CrossRef]

21. Cappelletti, P.; Colella, A.; Langella, A.; Mercurio, M.; Catalanotti, L.; Monetti, V.; De Gennaro, B. Use of surface modified natural zeolite (SMNZ) in pharmaceutical preparations Part 1. Mineralogical and technological characterization of some industrial zeolite-rich rocks. Microporous Mesoporous Mater. 2017, 250, 232-244. [CrossRef]

22. Cristofoletti, R.; Dressman, J.B. Dissolution methods to increasing discriminatory power of in vitro dissolution testing for ibuprofen free acid and its salts. J. Pharm. Sci. 2017, 106, 92-99. [CrossRef]

23. Coombs, D.S.; Alberti, A.; Armbruster, T.; Artioli, G.; Colella, C.; Galli, E.; Grice, J.D.; Liebau, F.; Mandarino, J.A.; Minato, H.; et al. Recommended nomenclature for zeolite minerals: Report of the subcommittee on zeolites of the International Mineralogical Association, Commission on new Minerals and Mineral names. Can. Mineral. 1997, 35, 1571-1606. [CrossRef]

24. Byrappa, K.; Kumar, B.V.S. Characterization of zeolites by infrared spectroscopy. Asian J. Chem. 2007, 19, 4933-4935. [CrossRef]

25. Karge, H.G. Characterization by IR spectroscopy. In Verified Syntheses of Zeolitic Materials; John Wiley Sons Inc.: New York, NY, USA, 2001; pp. 69-71. [CrossRef]

26. Mozgawa, W.; Król, M.; Barczyk, K. FT-IR studies of zeolites from different structural groups. Chem. Nauk. 2011, 1, 667-674.

27. Barczyk, K.; Mozgawa, W.; Król, M. Studies of anions sorption on natural zeolites. Spectrochim. Acta. A. Mol. Biomol. Spectrosc. 2014, 133, 876-882. [CrossRef] [PubMed]

28. Krajišnik, D.; Daković, A.; Malenović, A.; Kragović, M.; Milić, J. Ibuprofen sorption and release by modified natural zeolites as prospective drug carriers. Clay Miner. 2015, 50, 11-22. [CrossRef]

29. Krajišnik, D.; Daković, A.; Malenović, A.; Milojević, M.; Dondur, V.; Milić, J. Cationic surfactants-modified natural zeolites: Potential excipients for anti-inflammatory drugs. In Proceedings of the 3rd Croatian-Slovenian Symposium on Zeolites, Trogir, Croatia, 16-17 September 2010; pp. 23-26.

30. Wray, P.S.; Clarke, G.S.; Kazarian, S.G. Application of FTIR spectroscopic imaging to study the effects of modifying the pH microenvironment on the dissolution of ibuprofen from HPMC matrices. J. Pharm. Sci. 2011, 100, 4745-4755. [CrossRef] [PubMed]

31. Langmuir, I. the Constitution and Fundamental Properties of Solids and Liquids. Part I. Solids. J. Am. Chem. Soc. 1916, 252, 2221-2295. [CrossRef]

32. Sips, R. Combined form of Langmuir and Freundlich equations. J. Chem. Phys 1948, 16, 490-495. [CrossRef]

33. Toth, J. State equations of the solid-gas interface layers. Acta Chim Acad Sci Hungar 1971, 69, 311-328.

34. Li, Z.; Anghel, I.; Bowman, R.S. Sorption of Oxyanions By Surfactant-Modified Zeolite. J. Dispers. Sci. Technol. 1998, 19, 843-857. [CrossRef]

35. Li, Z.; Jones, H.K.; Bowman, R.S.; Helferich, R. Enhanced reduction of chromate and PCE by pelletized surfactant-modified zeolite/zerovalent iron. Environ. Sci. Technol. 1999, 33, 4326-4330. [CrossRef]

36. Krajišnik, D.; Milojević, M.; Malenović, A.; Daković, A.; Ibrić, S.; Savić, S.; Dondur, V.; Matijašević, S.; Radulović, A.; Daniels, R.; et al. Cationic surfactants-modified natural zeolites: Improvement of the excipients functionality. Drug Dev. Ind. Pharm. 2010, 36, 1215-1224. [CrossRef] [PubMed]

37. Li, Z.; Bowman, R.S. Sorption of chromate and PCE by surfactant-modified clay minerals. Environ. Eng. Sci. 1998, 15, 237-245. [CrossRef]

38. Li, Z.; Bowman, R.S. Counterion effects on the sorption of cationic surfactant and chromate on natural clinoptilolite. Environ. Sci. Technol. 1997, 31, 2407-2412. [CrossRef]

39. Li, Z.; Bowman, R.S. Regeneration of surfactant-modified zeolite after saturation with chromate and perchloroethylene. Water Res. 2001, 35, 322-326. [CrossRef] 
40. Janićijević, J.; Krajišnik, D.; Čalija, B.; Vasiljević, B.N.; Dobričić, V.; Daković, A.; Antonijević, M.D.; Milić, J. Modified local diatomite as potential functional drug carrier-A model study for diclofenac sodium. Int. J. Pharm. 2015, 496, 466-474. [CrossRef] [PubMed]

41. Foo, K.Y.; Hameed, B.H. Insights into the modeling of adsorption isotherm systems. Chem. Eng. J. 2010, 156, 2-10. [CrossRef]

42. Sauvé, S.; Desrosiers, M. A review of what is an emerging contaminant. Chem. Cent. J. 2014, 8, 1-7. [CrossRef] [PubMed]

43. Loos, R.; Carvalho, R.; António, D.C.; Comero, S.; Locoro, G.; Tavazzi, S.; Paracchini, B.; Ghiani, M.; Lettieri, T.; Blaha, L.; et al. EU-wide monitoring survey on emerging polar organic contaminants in wastewater treatment plant effluents. Water Res. 2013, 47, 6475-6487. [CrossRef] [PubMed]

44. Petrovic, M.; Eljarrat, E.; Lopez De Alda, M.J.; Barceló, D. Endocrine disrupting compounds and other emerging contaminants in the environment: A survey on new monitoring strategies and occurrence data. Anal. Bioanal. Chem. 2004, 378, 549-562. [CrossRef] [PubMed]

45. Tiedeken, E.J.; Tahar, A.; McHugh, B.; Rowan, N.J. Monitoring, sources, receptors, and control measures for three European Union watch list substances of emerging concern in receiving waters-A 20 year systematic review. Sci. Total Environ. 2017, 574, 1140-1163. [CrossRef] [PubMed]

46. Sousa, J.C.G.; Ribeiro, A.R.; Barbosa, M.O.; Pereira, M.F.R.; Silva, A.M.T. A review on environmental monitoring of water organic pollutants identified by EU guidelines. J. Hazard. Mater. 2018, 344, 146-162. [CrossRef] [PubMed]

47. Gros, M.; Petrović, M.; Ginebreda, A.; Barceló, D. Removal of pharmaceuticals during wastewater treatment and environmental risk assessment using hazard indexes. Environ. Int. 2010, 36, 15-26. [CrossRef]

48. Yang, Y.; Ok, Y.S.; Kim, K.H.; Kwon, E.E.; Tsang, Y.F. Occurrences and removal of pharmaceuticals and personal care products (PPCPs) in drinking water and water/sewage treatment plants: A review. Sci. Total Environ. 2017, 596-597, 303-320. [CrossRef] [PubMed]

49. Coelho, A.D.; Sans, C.; Esplugas, S.; Dezotti, M. Ozonation of NSAID: A Biodegradability and Toxicity Study. Ozone Sci. Eng. 2010, 32, 91-98. [CrossRef]

50. Kyzas, G.Z.; Fu, J.; Lazaridis, N.K.; Bikiaris, D.N.; Matis, K.A. New approaches on the removal of pharmaceuticals from wastewaters with adsorbent materials. J. Mol. Liq. 2015, 209, 87-93. [CrossRef]

51. Horcajada, P.; Márquez-Alvarez, C.; Rámila, A.; Pérez-Pariente, J.; Vallet-Regí, M. Controlled release of Ibuprofen from dealuminated faujasites. Solid State Sci. 2006, 8, 1459-1465. [CrossRef]

52. Smiljanić, D.; Daković, A.; Obradović, M.; Ožegović, M.; Izzo, F.; Germinario, C.; de Gennaro, B. Application of Surfactant Modified Natural Zeolites for the Removal of Salicylic Acid-A Contaminant of Emerging Concern. Materials 2021, 14, 7728. [CrossRef]

53. Whitney, D.L.; Evans, B.W. Abbreviations for names of rock-forming minerals. Am. Mineral. 2010, 95, 185-187. [CrossRef]

54. Pasquino, R.; Di Domenico, M.; Izzo, F.; Gaudino, D.; Vanzanella, V.; Grizzuti, N.; de Gennaro, B. Rheology-sensitive response of zeolite-supported anti-inflammatory drug systems. Colloids Surfaces B Biointerfaces 2016, 146, 938-944. [CrossRef] [PubMed]

55. Krajišnik, D.; Daković, A.; Milojević, M.; Malenović, A.; Kragović, M.; Bogdanović, D.B.; Dondur, V.; Milić, J. Properties of diclofenac sodium sorption onto natural zeolite modified with cetylpyridinium chloride. Colloids Surfaces B Biointerfaces 2011, 83, 165-172. [CrossRef] [PubMed]

56. Krajišnik, D.; Daković, A.; Malenović, A.; Milojević-Rakić, M.; Dondur, V.; Radulović, Ž.; Milić, J. Investigation of adsorption and release of diclofenac sodium by modified zeolites composites. Appl. Clay Sci. 2013, 83-84, 322-326. [CrossRef]

57. Jevtić, S.; Grujić, S.; Hrenović, J.; Rajić, N. Surfactant-modified clinoptilolite as a salicylate carrier, salicylate kinetic release and its antibacterial activity. Microporous Mesoporous Mater. 2012, 159, 30-35. [CrossRef]

58. Choi, J.; Shin, W.S. Removal of Salicylic and Ibuprofen by Hexadecyltrimethylammonium-Modified Montmorillonite and Zeolite. Minerals 2020, 10, 898. [CrossRef]

59. Rakić, V.; Rajić, N.; Daković, A.; Auroux, A. The adsorption of salicylic acid, acetylsalicylic acid and atenolol from aqueous solutions onto natural zeolites and clays: Clinoptilolite, bentonite and kaolin. Microporous Mesoporous Mater. 2013, 166, 185-194. [CrossRef] 